\title{
Temporal profile of body temperature in acute ischemic stroke: relation to stroke severity and outcome
}

\author{
Bartosz Karaszewski ${ }^{1,2}$, Ralph GR Thomas ${ }^{1,3}$, Martin S Dennis ${ }^{1}$ and Joanna M Wardlaw ${ }^{1,3^{*}}$
}

\begin{abstract}
Background: Pyrexia after stroke (temperature $\geq 37.5^{\circ} \mathrm{C}$ ) is associated with poor prognosis, but information on timing of body temperature changes and relationship to stroke severity and subtypes varies.

Methods: We recruited patients with acute ischemic stroke, measured stroke severity, stroke subtype and recorded four-hourly tympanic (body) temperature readings from admission to 120 hours after stroke. We sought causes of pyrexia and measured functional outcome at 90 days. We systematically summarised all relevant previous studies.

Results: Amongst 44 patients (21 males, mean age 72 years SD 11) with median National Institute of Health Stroke Score (NIHSS) 7 (range 0-28), 14 had total anterior circulation strokes (TACS). On admission all patients, both TACS and non-TACS, were normothermic (median $36.3^{\circ} \mathrm{C}$ vs $36.5^{\circ} \mathrm{C}, p=0.382$ respectively) at median 4 hours (interquartile range, IQR, 2-8) after stroke; admission temperature and NIHSS were not associated $\left(r^{2}=0.0, p=0.353\right)$. Peak temperature, occurring at 35.5 (IQR 19.0 to 53.8 ) hours after stroke, was higher in TACS $\left(37.7^{\circ} \mathrm{C}\right)$ than non-TACS $\left(37.1^{\circ} \mathrm{C}, \mathrm{p}<0.001\right)$ and was associated with admission NIHSS $\left(r^{2}=0.20, p=0.002\right)$. Poor outcome (modified Rankin Scale z3) at 90 days was associated with higher admission $\left(36.6^{\circ} \mathrm{C}\right.$ vs. $\left.36.2^{\circ} \mathrm{C} p=0.031\right)$ and peak $\left(37.4^{\circ} \mathrm{C}\right.$ vs. $37.0^{\circ} \mathrm{C}$, $\mathrm{p}=0.016$ ) temperatures. Sixteen (36\%) patients became pyrexial, in seven (44\%) of whom we found no cause other than the stroke.

Conclusions: Normothermia is usual within the first 4 hours of stroke. Peak temperature occurs at 1.5 to 2 days after stroke, and is related to stroke severity/subtype and more closely associated with poor outcome than admission temperature. Temperature-outcome associations after stroke are complex, but normothermia on admission should not preclude randomisation of patients into trials of therapeutic hypothermia.
\end{abstract}

Keywords: Ischemic stroke, Tympanic body temperature, Pyrexia, Outcome, OCSP

\section{Background}

Elevated body temperature (pyrexia) is said to be common after stroke $[1,2]$ and is associated with poor outcome [2-10]. However, the timing of pyrexia after stroke varied between studies (Table 1). Pyrexia occurring early might reflect the systemic response to ischemic brain damage [11] whereas pyrexia occurring later might be due to complications of severe stroke, such as infection and deep venous thrombosis (DVT). However data on timing,

\footnotetext{
* Correspondence: Joanna.Wardlaw@ed.ac.uk

${ }^{1}$ Division of Clinical Neurosciences, University of Edinburgh, Western General Hospital, Crewe Rd, Edinburgh EH4 2XU, UK

${ }^{3}$ SINAPSE Collaboration, Brain Research Imaging Centre, Division of Clinical Neurosciences, Western General Hospital, Crewe Rd, Edinburgh EH4 2XU, UK Full list of author information is available at the end of the article
}

causes and associations between body temperature and outcome vary.

Amongst the 18 previous studies of temperature after stroke (Tables 1 and 2), four performed only one temperature recording $[3,6,12,20]$, some measured temperature at admission but relatively late (e.g. 24 hours) [11] or at unspecified times after stroke $[2,4,7]$. Where serial readings were obtained, this was only up to three days after stroke $[8,9,13,15,18,22]$. Six studies included haemorrhagic and ischemic stroke [2-4,6,12,19]. Definitions of pyrexia, temperature measurement methods, reporting of associations with stroke severity and of causes of pyrexia varied widely $[2,7,10,14,16,17,21]$.

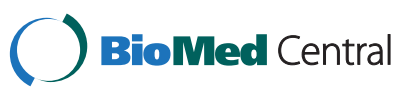


Table 1 Previous studies of body temperature and outcome after stroke - methods

\begin{tabular}{|c|c|c|c|c|c|c|c|c|}
\hline $\begin{array}{l}\text { First author } \\
\text { and year }\end{array}$ & $\begin{array}{l}\text { Study } \\
\text { design }\end{array}$ & $\mathrm{N}$ & Types of stroke & $\begin{array}{l}\text { Temperature } \\
\text { measurement } \\
\text { method }\end{array}$ & $\begin{array}{l}\text { Time of } 1^{\text {st }} \\
\text { interval; } \\
\text { last reading }\end{array}$ & Statistical analysis & Outcome measures & $\begin{array}{l}\text { Definition of } \\
\text { pyrexia }\end{array}$ \\
\hline $\begin{array}{l}\text { Azzimondi } \\
1995[2]\end{array}$ & $P$ & 183 & $\begin{array}{l}\text { Any stroke }<48 \text { hrs (not } \\
\text { SAH) }\end{array}$ & A & $\mathrm{N} / \mathrm{S} ; 12 \mathrm{~h} ; 7 \mathrm{~d}$ & Max temp in $7 \mathrm{~d}$, logistic regression & $\begin{array}{l}\text { CNS, serial GCS up to } 30 \mathrm{~d}, 1,3 \text { \& } \\
6 \text { month Barthel }\end{array}$ & $\begin{array}{l}\leq 37.2=\text { absence } \\
\text { of fever. } \geq 37.9= \\
\text { high fever }\end{array}$ \\
\hline Reith 1996 [3] & $P$ & 390 & Any stroke $<6$ hrs & T & $<6 \mathrm{~h} ;-;-$ & Logistic regression & $\begin{array}{l}\text { Lesion size, SSS, presence of } \\
\text { infection, WCC }\end{array}$ & $>37.5$ \\
\hline $\begin{array}{l}\text { Castillo } 1998 \\
\text { [9] }\end{array}$ & $P$ & 297 & Ischaemic & A & $<24 \mathrm{~h} ; 2 \mathrm{~h} ; 72 \mathrm{~h}$ & $\begin{array}{l}\text { Correlate peak temp with clinical } \\
\text { outcome and final infarct vol. Stepwise } \\
\text { logistic regression }\end{array}$ & $\begin{array}{l}\text { CSS, presence of infection, } 4-7 \mathrm{~d} \\
\text { lesion volume, } 3 \text { month Barthel }\end{array}$ & $>37.5$ \\
\hline $\begin{array}{l}\text { Georgilis } 1999 \\
\text { [4] }\end{array}$ & $\mathrm{R}$ & 330 & Any stroke & $\begin{array}{l}\text { Most A, some } \\
\text { RC }\end{array}$ & $<48 \mathrm{~h} ; 3 \mathrm{~h} ;-$ & $\begin{array}{l}\text { Presence/absence of fever and infection. } \\
\text { Stepwise logistic regression }\end{array}$ & $\begin{array}{l}\text { GCS, SSS, CT lesion volume, } \\
\text { presence of infection, use of } \\
\text { invasive procedures }\end{array}$ & $\begin{array}{l}>37.5 \text { on }>2 \\
\text { occasions on } 2 \\
\text { consec. days }\end{array}$ \\
\hline Wang 2000 [12] & $\mathrm{R}$ & 437 & Any "acute" stroke & T & $\begin{array}{l}\text { "Admission" but } \\
\text { no time limit } \\
\text { given; -; - }\end{array}$ & $\begin{array}{l}\text { Logistic regression. ischaemic vs. } \\
\text { haemorrhagic stroke }\end{array}$ & $\begin{array}{l}\text { Co-morbidities, WCC, [glucose], } \\
\text { mortality (in-hospital and } 1 \mathrm{yr} \text { ) }\end{array}$ & $>37.5$ \\
\hline Boysen 2001 [8] & $P$ & 584 & Ischaemic & T & $\begin{array}{l}<6 \text { h; } 2-4 h ; 48 \\
h\end{array}$ & Mean temp analysis by subgroup & SSS, 3 month mRS & $>37.5$ \\
\hline $\begin{array}{l}\text { Kammersgaard } \\
2002[6]\end{array}$ & $P$ & 390 & Any stroke & $\mathrm{T}$ & $<6 h ;-;-$ & $\begin{array}{l}\text { Dichotomised normothermia vs. pyrexia, } \\
\text { and multivariate survival analysis }\end{array}$ & SSS, [glucose], 5 yr mortality & $>37$ \\
\hline $\begin{array}{l}\text { Audebert } 2004 \\
\text { [13] }\end{array}$ & $\mathrm{R}$ & 346 & $\begin{array}{l}\text { Ischaemic; Excl pts with } \\
\text { infection pre- or post- } \\
\text { stroke }\end{array}$ & $\mathrm{O}$ or $\mathrm{RC}$ & $\begin{array}{l}<24 \mathrm{~h} \text { (mean } \\
6.7 \mathrm{~h}) ; 2-12 \mathrm{~h} ; 3 \\
\mathrm{~d}\end{array}$ & $\begin{array}{l}\text { Subgroup analysis of median temp days } \\
1-3\end{array}$ & $\begin{array}{l}\text { NIHSS, WCC, CRP, 1-5 d lesion } \\
\text { volume (CT/MR) }\end{array}$ & $\geq 37.5$ \\
\hline Sulter 2004 [1] & $P$ & 132 & $\begin{array}{l}\text { Ischaemic; Excl pts on } \\
\text { antibiotics on admission }\end{array}$ & $\mathrm{RC}$ & $\begin{array}{l}<12 \mathrm{~h} ; \\
\text { continuous; } 48 \\
\text { h }\end{array}$ & $\begin{array}{l}\text { Dichotomised according to hyperthermia } \\
\text { or not within } 48 \mathrm{~h}\end{array}$ & $\begin{array}{l}\text { baseline NIHSS, presence of } \\
\text { infection, effect of antipyretics }\end{array}$ & $>37.5$ \\
\hline Ernon 2006 [14] & $\mathrm{R}$ & 107 & $\begin{array}{l}\text { Ischaemic, with thrombo- } \\
\text { lysis }\end{array}$ & $\mathrm{T} / \mathrm{O}$ & $\begin{array}{l}<180 \mathrm{mins} ; \\
\text { random; } 24 \mathrm{~h}\end{array}$ & AUC relative to $37^{\circ}$ and to baseline $T^{\circ}$ & NIHSS, 3 month mRS & $>37.4$ \\
\hline Leira 2006 [11] & $P$ & 229 & $\begin{array}{l}\text { First ischaemic; Excl pts } \\
\text { with inflammatory or } \\
\text { infectious disease }\end{array}$ & A & $<24 \mathrm{~h} ;-;-$ & Presence vs. absence baseline pyrexia & $\begin{array}{l}\text { CSS, BP, blood biochemistry, 4-7 } \\
\text { d lesion volume (CT) }\end{array}$ & $\geq 37.5$ \\
\hline Wong 2007 [15] & $P$ & 156 & Ischaemic & T & $\begin{array}{l}<48 \mathrm{~h} \text { (median } \\
2.5 \mathrm{~h}) ; 4 \mathrm{~h} ; 48 \mathrm{~h}\end{array}$ & Mixed model, Lowess curves & $\begin{array}{l}\text { Baseline NIHSS, use of } \\
\text { paracetamol, presence of } \\
\text { infection }\end{array}$ & None \\
\hline $\begin{array}{l}\text { Idicula } 2008 \\
\text { [16] }\end{array}$ & $P$ & 127 & $\begin{array}{l}\text { Ischaemic with thrombo- } \\
\text { lysis }\end{array}$ & N/S & $\begin{array}{l}<3 \text { h; random; } 5 \\
d\end{array}$ & $\begin{array}{l}\text { Pre-thombolysis temperature and peak } \\
\text { temperature in } 5 d\end{array}$ & $\begin{array}{l}\text { NIHSS, } 3 \text { month mRS, BP, peak } \\
\text { [glucose] }\end{array}$ & $>37.7$ \\
\hline $\begin{array}{l}\text { Millan } 2008 \\
\text { [17] }\end{array}$ & $\mathrm{R}$ & 254 & $\begin{array}{l}\text { Ischaemic stroke with } \\
\text { thrombolysis }\end{array}$ & $\mathrm{N} / \mathrm{S}$ & $<3 \mathrm{~h} ; 6 \mathrm{~h} ; 48 \mathrm{~h}$ & $\begin{array}{l}\text { Pre-thrombolysis, temperature at } 24 \text { and } \\
48 \mathrm{~h} \text {, and peak temperature within } 24 \mathrm{~h} \\
\text { post- thrombolysis }\end{array}$ & $\begin{array}{l}\text { NIHSS, } 3 \text { month mRS, early lesion } \\
\text { vol (CT), MCA TIBI score (TCD) }\end{array}$ & $\geq 37$ \\
\hline Saini 2009 [7] & R & 5305 & First ischaemic & $\begin{array}{l}\text { Most patients: } \\
\mathrm{A} \text {; others N/S }\end{array}$ & $\begin{array}{l}\text { N/S; } 8 \text { then } 24 \\
\text { hrly; } 7 \mathrm{~d}\end{array}$ & $\begin{array}{l}\text { Normotherm vs. pyrexia at different time } \\
\text { points }\end{array}$ & $\begin{array}{l}\text { WCC, NIHSS, } 3 \text { month mRS, lesion } \\
\text { vol (1-7 d CT/MR), use of } \\
\text { antibiotics }\end{array}$ & $>37.2$ \\
\hline
\end{tabular}

\section{$<6 \mathrm{~h} ; 2$}

$<24 \mathrm{~h}$ (mean Subgroup analysis of median temp days $6.7 \mathrm{~h}) ; 2-12 \mathrm{~h} ; 3 \quad 1-3$ andom; $24 \mathrm{~h}$

$<8 \mathrm{~h}$ (median Mixed model, Lowess curves

$<3$ h; random; 5 Pre-thombolysis temperature and peak 
Table 1 Previous studies of body temperature and outcome after stroke - methods (Continued)

\begin{tabular}{|c|c|c|c|c|c|c|c|c|}
\hline $\begin{array}{l}\text { den Hertog } \\
\text { (PAIS) 2009 \& } \\
2011[18,19]\end{array}$ & P RCT & $\begin{array}{l}13990 r \\
1332\end{array}$ & Any stroke $<12$ hrs & $\mathrm{T}$ or $\mathrm{RC}$ & $\begin{array}{l}\text { median } 6 \mathrm{~h} \text {, all } \\
<12 \mathrm{~h} ;-;-\end{array}$ & Multiple logistic regression & $\begin{array}{l}\text { baseline NIHSS, } 14 \text { d Barthel, } 3 \\
\text { month mRS }\end{array}$ & None \\
\hline Naess 2010 [20] & R & $\begin{array}{l}250 \\
(111 \text { vs. } \\
139)\end{array}$ & Ischaemic & $N / S$ & $<6 \mathrm{~h} ;-;-$ & $\begin{array}{l}\text { Logistic regression, temperature against } \\
\text { outcome in tPA-treated vs. non-treated } \\
\text { patients }\end{array}$ & $\begin{array}{l}\text { baseline NIHSS, mRS on day } 7 \text { or } \\
\text { at discharge, vascular risk factors, } \\
\text { stroke aetiology }\end{array}$ & None \\
\hline $\begin{array}{l}\text { Phipps } 2011 \\
\text { [21] }\end{array}$ & R & 1361 & Ischaemic, NIHSS $\geq 2$ & $\begin{array}{l}\text { Majority - T, } \\
\text { partially } \\
\text { unknown }\end{array}$ & $<48 \mathrm{~h} ;-;-$ & Logistic regression & $\begin{array}{l}\text { vascular risk factors, NIHSS, stroke } \\
\text { aetiology }\end{array}$ & $\geq 37.8$ \\
\hline
\end{tabular}

P: prospective; SAH: subarachnoid haemorrhage; A: axillary; N/S: not specified; h: hours; d: days; CNS: Canadian Neurological Scale; GCS: Glasgow Coma Score; T: tympanic; SSS: Scandinavian Stroke Scale Score; WCC: white cell count; CSS: Canadian Stroke Scale; R: retrospective; RC: rectal; CT: computed tomography; mRS: modified Rankin Score; O: oral; NIHSS: National Institutes of Health Stroke Scale; CRP: C reactive protein; MR: magnetic resonance; AUC: area under the curve; BP: blood pressure; MCA: middle cerebral artery; TIBI: thrombolysis in brain ischaemia; TCD: transcranial Doppler; tPA: tissue plasminogen activator. 
Table 2 Previous studies of body temperature and outcome after stoke - key results

\begin{tabular}{ll}
\hline First author and year & Key findings \\
\hline Azzimondi 1995 [2] & High fever $\left(\geq 37.9^{\circ} \mathrm{C}\right)<7 \mathrm{~d}$ is independent risk factor for poor prognosis. Fever occurred in $43 \%$ of stroke pts $<7 \mathrm{~d}$. \\
& Onset of fever occurred in first 2 days in $64 \%$ of febrile patients.
\end{tabular}

Reith 1996 [3]

Castillo 1998 [9]

Georgilis 1999 [4]

Wang 2000 [12]

Boysen $2001[8]$

Kammersgaard 2002 [6]

Audebert 2004 [13]

Sulter 2004 [1]

Ernon 2006 [14]

Leira 2006 [11]

Wong 2007 [15]

Idicula 2008 [16]

Millan 2008 [17]

Saini 2009 [7]

den Hertog (PAIS) 2009 \&

$2011[18,19]$

Naess 2010 [20]

Phipps 2011 [21]

Admission body temp is independently related to stroke severity, lesion size, mortality and outcome. [unclear how measured "outcome"; didn't separate AlS from ICH]

The relationship between the degree of hyperthermia and stroke outcome/FIV is strongest when it begins within $24 \mathrm{~h}$ of symptom onset.

Fever in stroke is assoc with $\uparrow a g e, \uparrow s e v e r i t y$, more invasive techniques, worse outcome. When fever present without focus of infection, it tends to occur earlier.

For ischaemic stroke, admission temp (time unspecified) was significant predictor of in-hospital mortality: for each $1^{\circ}$ increase, $\mathrm{OR} \uparrow$ by $3.9(\mathrm{Cl} 1.9$ to $7.8, \mathrm{p}<0.001)$.

Temp $<6 \mathrm{~h}$ post stroke onset has no prognostic influence on 3 month mRS. More severe strokes have higher temperature in first $48 \mathrm{~h}$. [Also looked at ICH]. $7 \mathrm{~d}$ fatality rate higher in patients with lower body temp on admission.

For all strokes, a $1^{\circ}$ difference in admission body temperature gives $30 \%$ increase in relative risk of $5 \mathrm{yr}$ mortality. No association between admission temp and survival in pts still alive at 3 months.

Larger stroke volume and greater NIHSS assoc with higher temp, CRP and WCC. Successful thrombolysis attenuates inflammatory response

$56 \%$ developed hyperthermia in $1^{\text {st }} 48 \mathrm{~h}$. Infectious cause found in 1/3 of patients.

Hyperthermia relative to baseline in $24 \mathrm{~h}$ (post rtPA) is assoc with unfavourable outcome

Hyperthermia assoc with higher levels of proinflammatory markers. Inflammatory mediators play a role in acute ischaemic brain damage independently of hyperthermia

Mean temp rise in first $24 \mathrm{~h}$ from 36.5 to $36.7^{\circ}$, peak at $36 \mathrm{~h}$. More severe strokes have higher temp rise.

Body temp before thrombolysis was not assoc with 3 month outcome, but high temp thereafter was.

Body temp $\geq 37$ at $24 \mathrm{~h}$ but not at baseline was assoc with lack of recanalisation, greater hyperdensity volume and worse functional outcome, regardless of stroke severity and time to treatment

Hyperthermia assoc with poor outcome. Delayed hyperthermia is more strongly assoc with poor outcomes than early hyperthermia. No association between baseline hyperthermia and outcome.

Baseline body temp was not related to improvement. Increased body temp at $24 \mathrm{~h}$ was associated with low likelihood of improvement.

High body temperature was associated with favorable short-term outcome in those who were thrombolysed vs. those not thrombolysed

High "fever burden" (combination of fever height and duration) was associated with death or with referral to hospice

d: days; AIS: acute ischemic stroke; ICH: intracerebral haemorrhage; FIV: final infarct volume; h: hours; OR: odds ratio; Cl: confidence interval; mRS: modified Rankin Score; NIHSS: National Institutes of Health Stroke Scale; CRP: C reactive protein; WCC: white cell count; rtPA: recombinant tissue plasminogen activator.

Thus, while some studies found associations between higher admission temperature and poor outcome (Table 2) $[3,6,12]$, others found that peak temperature occurring several days after stroke, not admission temperature, was associated with poor outcome $[7,16,17,19]$. The reasons for these differences are unclear but important to understand to limit brain damage and improve outcome after stroke.

We obtained measurements of body temperature every four hours from admission to five days after acute ischemic stroke as part of a study to examine serial changes in the ischaemic lesion on MR imaging. We used these data to clarify the temporal profile, associations with stroke severity, subtype and functional outcome and proportion with an alternative explanation for pyrexia.

\section{Methods}

We prospectively recruited patients $>18$ years old who presented with potentially disabling ischemic stroke. We excluded patients with intracerebral haemorrhage (ICH), coma, serious intercurrent illness, and technical or clinical incompatibility with MR scanning. Ethical approval was granted by the Scottish Multi-Centre Research Ethics Committee (06/MRE00/119) and we obtained informed, written consent from all patients or their relatives.

At admission, we recorded National Institute of Health Stroke Score (NIHSS) and the Oxford Community Stroke Project (OCSP) stroke subtype classification [23]. All patients underwent MR imaging to diagnose the ischemic stroke. We recorded temperature using a First Temp Genius ${ }^{\circledR}$ tympanic thermometer immediately on 
arrival at hospital, and four hourly thereafter up to 120 hours. Recordings were taken from the uppermost ear in most patients, and from both ears in 11 patients to test side-to-side variation [24]. Tympanic thermometry is considered reliable for serial readings [25], shows the least variation with age compared with axillary, rectal and oral thermometry [26], and is widely used in clinical practice. Pyrexia was defined as temperature $\geq 37.5^{\circ} \mathrm{C}$ [10]. We searched for causes of pyrexia by collecting data on evidence of infection (evident infectious agent, leukocytes in body fluid, signs on imaging), DVT and surgical intervention as well as paracetamol and antibiotic use. Our policy is to prescribe paracetamol to patients who develop pyrexia (or for other indications such as pain relief) and antibiotics when positive evidence of infection and an infectious agent is diagnosed. We recorded modified Rankin Scale score (mRS) at three months after stroke, blind to temperature measurements.

We compared admission, peak and final temperatures and calculated area under the temperature/time curve (AUC) [27] which we standardised $\left(\mathrm{AUC}_{[\mathrm{s}]}\right)$ by assuming all patients had a temperature of $36.5^{\circ} \mathrm{C}$ between stroke and the admission recording, and dividing AUC by the time of final temperature reading [27]. We tested the association between temperature profile and measures of stroke severity firstly as determined by NIHSS, secondly by comparing total anterior circulation strokes (TACS) vs. less severe stroke subtypes (non-TACS) and thirdly good $(m R S \leq 2)$ vs. poor $(m R S \geq 3) 90$ day outcome. We adjusted analysis for age and admission NIHSS where appropriate. We used Student's t-test for parametric and Mann Whitney U tests and Spearman correlation for non-parametric data.

\section{Results}

Between $7^{\text {th }}$ December 2007 and $24^{\text {th }}$ March 2009, we recruited 48 patients but excluded two with $\mathrm{ICH}$, one with complex migraine and one with functional limb weakness, leaving 44 with acute ischemic stroke (21 males) of median age 74 years (range 37-88) and median admission NIHSS 7 (range 0-28). There were 14 TACS and 30 non-TACS (Table 3). Twenty-five patients had poor $(\mathrm{mRS} \geq 3)$ and 19 had good $(\mathrm{mRS} \leq 2) 90$ day functional outcomes. Patients with poor outcome were older $(75 \pm 10)$ with higher admission NIHSS $(13 \pm 7)$ than patients with good outcome ( $68 \pm 11$ and $5 \pm 4$ respectively).

There was no difference between ipsi- and contralateral tympanic temperature readings obtained simultaneously $\left(36.6^{\circ} \mathrm{C}\right.$ vs $36.6^{\circ} \mathrm{C}, 95 \%$ confidence interval (CI) -0.19 to $0.16, p=0.821$ ) in 11 patients (five TACS). The mean number of temperature readings per patient was 14 (SD 6.9). No patients died during the observation period.
When temperature was first measured on admission, at a median 4 (interquartile range (IQR) 2 to 7.8 ) hours after stroke, all patients were normothermic (mean $36.4^{\circ} \mathrm{C}$, 95\% CI 36.2 to 36.6) (Table 3). Peak temperature (mean $37.3^{\circ} \mathrm{C}, 95 \%$ CI 37.1 to 37.5 ) occurred at median 35.5 hours (IQR 19.0-53.8) after stroke. The latest temperature (mean $36.5^{\circ} \mathrm{C}, 95 \%$ CI 36.3 to 36.7 ) was recorded at median 108.5 hours (IQR 98.8-113.5) after stroke.

Admission NIHSS score was not associated with admission temperature (adjusted $\mathrm{r}^{2}=0.0, \mathrm{p}=0.353$ ), but was associated with peak (adjusted $\mathrm{r}^{2}=0.20, \mathrm{p}=0.002$ ), and final (adjusted $\mathrm{r}^{2}=0.25, \mathrm{p}=0.001$ ) temperatures. NIHSS was also associated with the overall temperature profile AUC[s] (adjusted $\mathrm{r}^{2}=0.07, \mathrm{p}=0.047$ ).

Admission temperature in TACS (mean $36.3^{\circ} \mathrm{C}, 95 \% \mathrm{CI}$ 35.9-36.7) was similar to temperature in non-TACS $\left(36.5^{\circ} \mathrm{C}, 95 \% \mathrm{CI} 36.3-36.6\right)$ patients $(\mathrm{p}=0.382)$, measured at median 3.5 hours (IQR 1.0-6.0) in TACS, and 4 hours (IQR 2.0-8.8) in non-TACS ( $\mathrm{p}=0.258$, Mann Whitney $\mathrm{U}$ test), Table 4, Figure 1. However, peak temperature was higher in TACS (mean $37.7^{\circ} \mathrm{C}$, 95\% CI 37.5-37.9) than in non-TACS $\left(37.1^{\circ} \mathrm{C}, 95 \% \mathrm{CI} 36.9-37.3, \mathrm{p}<0.001\right)$, occurring at median 46.0 hours in TACS and 32.5 hours in non-TACS ( $\mathrm{p}=0.199$, Mann Whitney U test). Final temperature was also higher in TACS (mean $\left.36.8^{\circ} \mathrm{C}, 95 \% \mathrm{CI} 36.6-37.0\right)$ than non-TACS $\left(36.3^{\circ} \mathrm{C}, 95 \%\right.$ CI 36.1-36.6, $\mathrm{p}=0.002)$ patients, and occurred later in TACS (median 117.5 hours, IQR 107.5-119.8) than in non-TACS patients (107.5 hours, IQR 94.3-111.5, $\mathrm{p}=0.007$ Mann Whitney U test). Consequently, TACS patients had a larger $\mathrm{AUC}_{[\mathrm{s}]}(36.6,95 \% \mathrm{CI} 36.5-36.8)$ than non-TACS patients $(36.4,95 \%$ CI 36.3-36.5, $\mathrm{p}=0.019)$. This is demonstrated graphically in Figure 2. Detailed temperature profiles for TACS and non-TACS patients are provided in Additional file 1: Figure S1a and b.

Admission temperature was higher in the 25 patients with poor outcome $\left(36.6^{\circ} \mathrm{C}, 95 \% \mathrm{CI} 36.3-36.8\right)$ than in the 19 patients with good outcome $\left(36.2^{\circ} \mathrm{C}, 95 \% \mathrm{CI}\right.$ 36.0-36.4, $\mathrm{p}=0.031)$ at 90 days. Peak temperature was also higher in patients with poor outcome $\left(37.4^{\circ} \mathrm{C}, 95 \%\right.$ CI 37.2-37.6) than in patients with good outcome, $\left(37.0^{\circ} \mathrm{C}\right.$, 95\% CI 36.8-37.3, $\mathrm{p}=0.016$ ) (Figure 3). A higher proportion of patients with pyrexia $(12 / 16,75 \%)$ had a poor 90 day outcome than did patients without pyrexia (13/28, $46 \%$ ), odds ratio (OR) $3.46,95 \%$ CI 0.89 to 13.39 ) (Table 3).

Sixteen (36\%) patients became pyrexial (at least one temperature reading of $\geq 37.5^{\circ} \mathrm{C}$ ) during the recording period: 9/14 (64\%) TACS patients and 7/30 (23\%) nonTACS $\left(\chi^{2}=6.9, p=0.009\right)$. Of the 16 pyrexial patients, at least one potential cause of pyrexia was identified in nine (56\%), but $11 / 16(69 \%)$ had no infection and 7/16 (44\%) had no identified cause for pyrexia (apart from the 
Table 3 Baseline data, pyrogenic factors and use of antibiotics and thrombolysis

\begin{tabular}{|c|c|c|c|c|c|}
\hline & & Total $n=44$ & No pyrexia $n=28$ & Pyrexia $n=16$ & \\
\hline \multicolumn{6}{|l|}{ Sex } \\
\hline & Male & 21 & 15 & 6 & \\
\hline & Female & 23 & 13 & 10 & \\
\hline Mean Age in years, (SD) & & $71.9(11.4)$ & $71.9(11.7)$ & $71.9(11.3)$ & $p=0.990$ \\
\hline \multicolumn{6}{|l|}{ Stroke Subtype } \\
\hline & TACS & 14 & 5 & 9 & TACS vS \\
\hline & PACS & 19 & 14 & 5 & non-TACS \\
\hline & LACS & 6 & 6 & 0 & $x^{2}=6.9$ \\
\hline & POCS & 5 & 3 & 2 & $p=0.009$ \\
\hline \multicolumn{6}{|l|}{ Stroke severity } \\
\hline & Median NIHSS (IQR) & $7(3-14)$ & $6.5(3-10)$ & $12(5-18)$ & $\mathrm{p}=0.0381(\mathrm{MWU})$ \\
\hline \multicolumn{6}{|l|}{ Temperature } \\
\hline & $\begin{array}{l}\text { Time to peak, median hours } \\
\text { after stroke, (IQR) }\end{array}$ & $35.5(19-53.8)$ & $36.0(7.8-59.3)$ & $32.5(22.8-51.3)$ & $\mathrm{p}=0.652(\mathrm{MWU})$ \\
\hline \multirow[t]{7}{*}{$\mathrm{N}^{\circ}$. with $\geq 1$ pyrogenic factor identified* } & & $16(36 \%)$ & $7(25 \%)$ & $9(56 \%)$ & \\
\hline & Urinary catheter & 8 & 3 & 5 & \\
\hline & NG tube & 9 & 4 & 5 & \\
\hline & Surgical procedure & 4 & 2 & 2 & \\
\hline & DVT & 0 & 0 & 0 & \\
\hline & Infection: urinary & 2 & 0 & 2 & \\
\hline & Infection: respiratory & 7 & 4 & 3 & \\
\hline Antibiotics & & 10 & $4(14 \%)$ & $6(38 \%)$ & \\
\hline Paracetamol & & 13 & $7(25 \%)$ & $6(38 \%)$ & \\
\hline Thrombolysis & & 3 & $1(4 \%)$ & $2(13 \%)$ & \\
\hline \multicolumn{6}{|l|}{90 day $\mathrm{mRS}$} \\
\hline & $\mathrm{mRS} \leq 2$ & 19 & 15 & 4 & $x^{2}=3.5$ \\
\hline & $m R S \geq 3$ & 25 & 13 & 12 & $p=0.061$ \\
\hline
\end{tabular}

*Some patients had more than 1 potential cause of pyrexia. Pyrexia was defined as tympanic temperature $\geq 37.5^{\circ} \mathrm{C}$. SD: standard deviation; TACS: total anterior circulation stroke; PACS: partial anterior circulation stroke; LACS: lacunar stroke; POCS: posterior circulation stroke; NIHSS: National Institute of Health Stroke Score; IQR: interquartile range; MWU: Mann Whitney U test; NG: nasogastric; DVT: deep venous thrombosis; mRS: modified Rankin Score.

stroke). Conversely, a potential pyrogenic factor was identified in $7 / 28(25 \%)$ patients without pyrexia (Table 3). Thirteen patients were prescribed paracetamol of whom seven were recorded as having pyrexia and six were not (OR for pyrexia associated with paracetamol=1.8, 95\% CI
0.48 to 6.77). The reason for paracetamol administration in the patients without pyrexia was mostly for pain relief. Ten patients with poor outcome $(40 \%)$ had been prescribed paracetamol but only in three (16\%) patients with good outcome (OR for poor outcome 3.56, 95\% CI 0.82 to 15.46).

Table 4 Mean admission, peak and final body temperatures in patients grouped according to OCSP classification

\begin{tabular}{|c|c|c|c|c|c|c|}
\hline $\begin{array}{l}\text { Stroke subtype } \\
\text { (OCSP) }\end{array}$ & $\mathrm{n}$ & $\begin{array}{l}\text { Admission temperature }{ }^{\circ} \mathrm{C} \\
(95 \% \mathrm{Cl})\end{array}$ & $\begin{array}{l}\text { Peak temperature }{ }^{\circ} \mathrm{C} \\
(95 \% \mathrm{Cl})\end{array}$ & $\begin{array}{l}\text { Final temperature }{ }^{\circ} \mathrm{C} \\
(95 \% \mathrm{Cl})\end{array}$ & $\begin{array}{l}90 \text { day } \mathrm{mRS} 0 \text { to } \\
2(\mathrm{n})\end{array}$ & $\begin{array}{l}90 \text { day } \mathrm{mRS} 3 \text { to } \\
6(\mathrm{n})\end{array}$ \\
\hline TACS & 14 & $36.3(35.9-36.7)$ & $37.7(37.5-37.9)$ & $36.8(36.6-37.0)$ & 2 & 12 \\
\hline PACS & 19 & $36.4(36.2-36.6)$ & $37.0(36.8-37.3)$ & $36.3(36.0-36.7)$ & 11 & 8 \\
\hline LACS & 6 & 36.7 (36.4-36.9) & $37.0(36.7-37.2)$ & $36.2(36.0-36.3)$ & 3 & 3 \\
\hline POCS & 5 & $36.6(35.8-37.4)$ & $37.3(36.5-38.1)$ & $36.5(36.0-36.9)$ & 3 & 2 \\
\hline Total & 44 & $36.4(36.3-36.6)$ & $37.3(37.1-37.4)$ & $36.5(36.3-36.7)$ & 19 & 25 \\
\hline
\end{tabular}

OCSP: Oxford Community Stroke Project; Cl: confidence interval; TACS: total anterior circulation stroke; PACS: partial anterior circulation stroke; LACS: lacunar stroke; POCS: posterior circulation stroke; mRS: modified Rankin Score. 


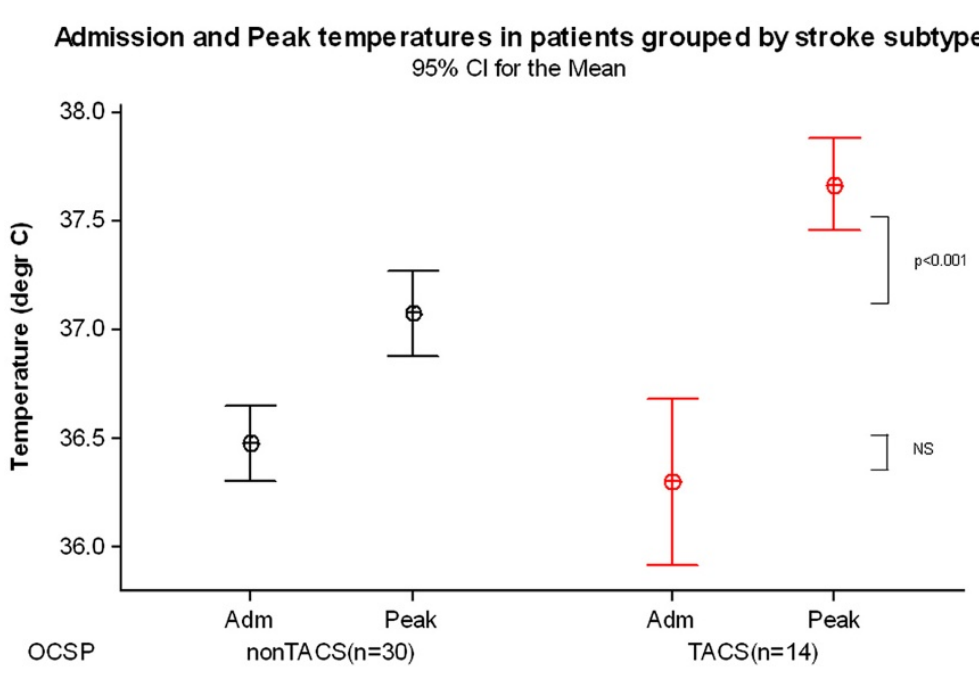

Figure 1 Admission, peak and final temperature in TACS $(n=14)$ and non-TACS patients $(n=30)$.

\section{Discussion}

In patients with ischemic stroke, tympanic temperature was not elevated on admission even in patients with more severe strokes (TACS), and admission temperature did not correlate with admission NIHSS. Instead, we found that peak temperature, occurring at around 1.5 to 2 days after stroke and overall temperature, as expressed by AUC were associated with admission stroke severity as measured by NIHSS and TACS subtype. Peak temperatures were higher, occurred later and temperature elevation lasted longer in more severe than less severe strokes perhaps indicating a more prolonged, greater inflammatory response to the volume of infarcted tissue. Patients with poor functional outcome $(\mathrm{mRS} \geq 3)$ at 90 days had higher admission and peak temperatures than patients with good outcome $(\mathrm{mRS} \leq 2)$, although all admission temperatures

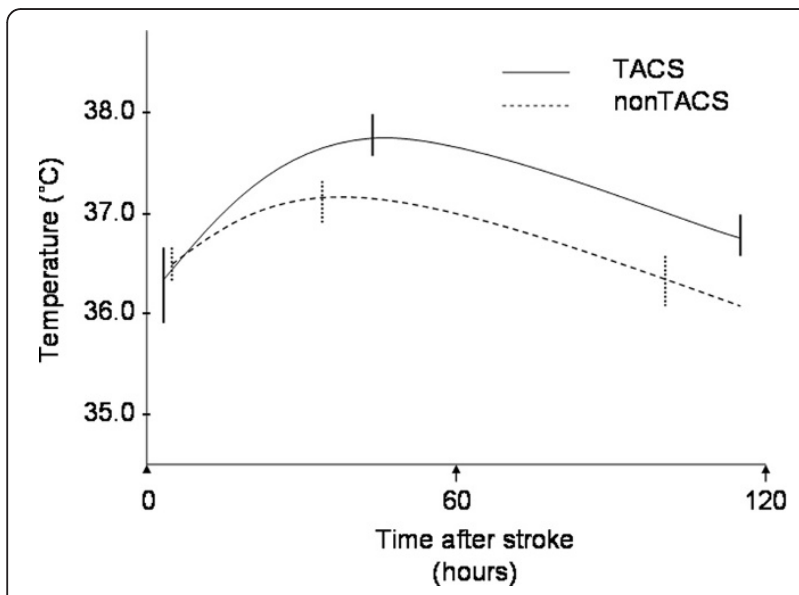

Figure 2 Body temperature profiles of patients with severe stroke (TACS) and milder stroke (non-TACS). Mean temperatures and 95\% confidence intervals are shown for admission, peak and final temperature readings, averaged across all patients. were $<37^{\circ} \mathrm{C}$. We were not able to find a source of infection in $69 \%$ of pyrexial patients, and no alternative cause of pyrexia, other than the stroke itself, in $44 \%$.

This prospective study of detailed four-hourly tympanic temperature measurements up to five days after ischemic stroke helps explain the varying results of previous studies (Tables 1 and 2) some of which found associations between admission temperature, stroke severity and outcome $[3,4,6,12,13]$, while others did not $[8,14,16,19]$. This variation can be attributed to some studies being retrospective, or not specifying the timing of temperature recording after stroke, sampling temperature only once, measuring "admission" temperature relatively late after stroke, only measuring serial temperature up to 72 hours, the different severities of stroke included in each study or including patients with both haemorrhagic and ischemic stroke. Consistent with our results, others showed that patients with more severe strokes experience higher peak temperatures [15], and that elevated temperature at 24 hours [14,17,19], 48 hours [8] or 7 days [7] after stroke was more closely linked to poor outcome than admission readings. Our detailed longitudinal findings also demonstrate the higher, later and longer duration of temperature elevation in more severe than less severe stroke, which perhaps has not been appreciated previously.

Our study has limitations. The small sample size was constrained by selection of patients for an MR imaging study, but on the other hand it allowed very detailed temperature monitoring. However, the range of stroke severity was consistent with those that would be considered for trials of therapeutic hypothermia. A larger sample size would allow more adjustment for potential confounders, and clarification of the significance of any differences in timing of peak temperature readings, and comparison of patients whose tympanic temperature 


\section{Admission and Peak Body Temperature by 90 day mRS}

$95 \% \mathrm{Cl}$ for the Mean

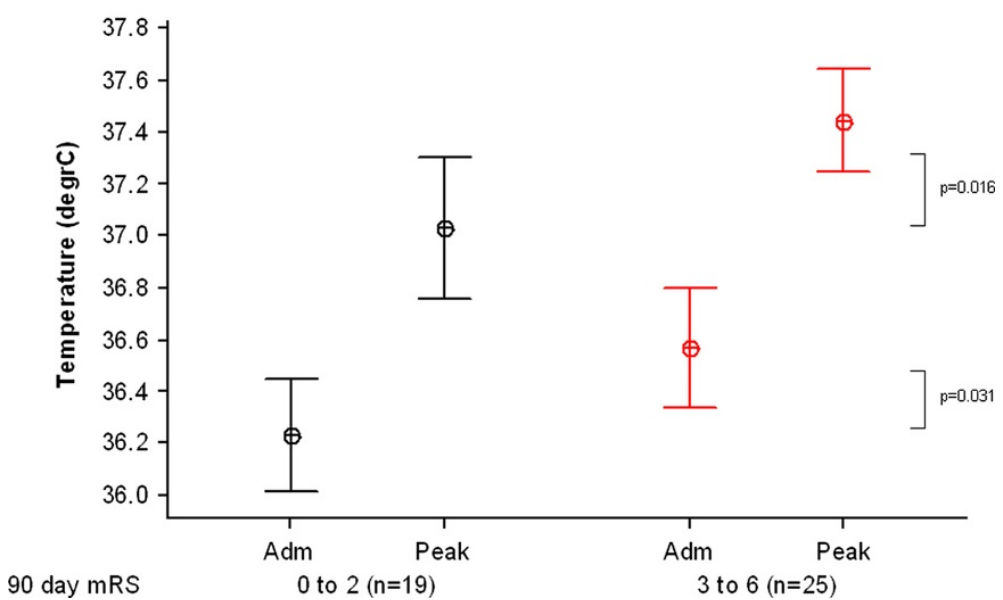

Figure 3 Admission, peak and final temperature by 90 day outcome ( $m R S \leq 2, n=19 ; m R S \geq 3, n=25$ ).

may have been affected by antibiotics and antipyretics, although our results show that pyrexia was just as common in patients who were prescribed paracetamol as in those who were not, in contrast to others' results [15]. However paracetamol may have influenced the profile of temperature change. Although our data on temperature profile and stroke severity are consistent with five previous studies, we cannot exclude the possibility of an association between admission temperature and stroke severity. The study strengths are the detailed four-hourly tympanic temperature measurements for 120 hours after ischemic stroke and the detailed comparison with stroke subtype, severity and outcome. The duration of temperature recording ensured that the peak temperature was captured in both TACS and non-TACS.

Two other points raise questions for further study. Admission temperature in the patients with more severe strokes, ie TACS, was not higher than in patients with milder strokes, as might have been expected. Perhaps, by analogy with other serious acute illness, the temperature in severe stroke may reflect severe illness [28]. Secondly, why do patients with a poor outcome have a marginally higher (but still normothermic) admission temperature, and while severe stroke is associated with poor outcome, severe stroke is not associated with admission temperature? This might be explained at least in part by a possible cascade of events suggested in experimental data. Increased temperature opens the blood-brain barrier [29] which, in acute ischemia, would lead to increased extracellular oedema, more infarct swelling, more restricted capillary flow in the ischemic tissue, less chance of reperfusion, all contributing to increasing ischemic damage, swelling and leading to a larger infarct around 48 hours [30], consolidating the potential for tissue damage that was suggested by the severe stroke symptoms at presentation, and consequently leading to the poor outcome at 90 days. Longer duration of temperature monitoring should be considered in future research to improve understanding of temperature profiles after stroke.

This interpretation, if true, raises some implications for therapeutic hypothermia trials. Firstly, and paradoxically, patients may benefit the most from hypothermia if it prevents the tissue cascade outlined above from causing more tissue damage and should certainly not be excluded from trials; thus cooling should be initiated as early as possible and not influenced by the patient's admission temperature. However cooling may only prevent worsening of damage, not actively salvage tissue that is already at risk, so combinations of therapies to salvage (e.g. thrombolysis) as well as to restrict progressive new damage (e.g. hypothermia, if it works) may be required. Secondly, if the main effect of hypothermia is to reduce blood-brain barrier opening thus preventing the cascade that leads to larger stroke lesions, then hypothermia could still be valuable if started many hours after the stroke when the possibility of salvaging at risk tissue was lost but there was still some "future secondary damage" to prevent. If correct, then hypothermia should reduce subacute infarct oedema and mass effect. Thirdly, if correct, then therapeutic thrombolysis and hypothermia should work synergistically to produce greater benefit than either alone. However hypothermia may also have some disadvantages. In addition to increased risk of secondary infection and the need to manage unpleasant side effects like shivering, lower temperatures might delay thrombus lysis which pyrexia might accelerate. The balance of risk and benefit presented by these possibilities requires testing in future therapeutic trials of hypothermia after stroke. 


\section{Conclusion}

The association between body temperature, stroke severity and functional outcome is complex and, if our observations in this small detailed study are verified, then even very marginal differences in admission temperature in normothermic patients may provide a mechanism whereby, for a given stroke severity, potential tissue damage is converted into more severe damage resulting in a poor outcome, which might be prevented by therapeutic hypothermia.

\section{Additional file}

Additional file 1: Figure S1. (online only). Individual patient body temperature profiles for (a) non-TACS and (b) non-TACS patients. These graphs show mean body temperature values over 120 hours after stroke onset with nonlinear regression curves.

\section{Competing interests}

J Wardlaw is the Imaging Workpackage Lead for the EuroHyp trial of therapeutic hypothermia in stroke. The work was conducted prior to and independently of the EuroHyp trial. The authors have no other competing interests.

\section{Authors' contributions}

RGR Thomas and B Karaszewski recruited patients, collected and entered data in to the database and performed initial analysis. MS Dennis supervised the clinical stroke examination and subtyping. JM Wardlaw initiated and supervised the project, checked the data, and with RG Thomas, drafted and with all authors, edited the manuscript. All authors have read and approved the final manuscript.

\section{Acknowledgements}

We thank the UK Stroke Research Network nurses who performed the serial temperature measurements. RGT was funded by The Stroke Association (Registered Charity SC037789), Project Ref No: TSA 2006/11, BK by the Foundation for Polish Science and the International Brain Research Organization (IBRO), JMW by the Scottish Funding Council SINAPSE Collaboration (www.sinapse.ac.uk).

\section{Author details}

${ }^{1}$ Division of Clinical Neurosciences, University of Edinburgh, Western General Hospital, Crewe Rd, Edinburgh EH4 2XU, UK. ²Department of Adult Neurology, Medical University of Gdansk, Poland. ${ }^{3}$ SINAPSE Collaboration, Brain Research Imaging Centre, Division of Clinical Neurosciences, Western General Hospital, Crewe Rd, Edinburgh EH4 2XU, UK.

Received: 21 April 2012 Accepted: 11 October 2012

Published: 18 October 2012

\section{References}

1. Sulter G, Elting JW, Maurits N, Luijckx GJ, De KJ: Acetylsalicylic acid and acetaminophen to combat elevated body temperature in acute ischemic stroke. Cerebrovasc Dis 2004, 17:118-122.

2. Azzimondi G, Bassein L, Nonino F, Fiorani L, Vignatelli L, Re G, D'Alessandro $\mathrm{R}$ : Fever in acute stroke worsens prognosis. A prospective study. Stroke 1995, 26:2040-2043.

3. Reith J, Jorgensen HS, Pedersen PM, Nakayama H, Raaschou HO, Jeppesen $\mathrm{LL}$, Olsen TS: Body temperature in acute stroke: relation to stroke severity, infarct size, mortality, and outcome. Lancet 1996, 347:422-425.

4. Georgilis K, Plomaritoglou A, Dafni U, Bassiakos Y, Vemmos K: Aetiology of fever in patients with acute stroke. J Int Med 1999, 246:203-209.

5. Hajat $C$, Hajat $S$, Sharma P: Effects of poststroke pyrexia on stroke outcome: a meta-analysis of studies in patients. Stroke 2000, 31:410-414.

6. Kammersgaard LP, Jorgensen HS, Rungby JA, Reith J, Nakayama H, Weber UJ, Houth J, Olsen TS: Admission body temperature predicts long-term mortality after acute stroke: the Copenhagen Stroke Study. Stroke 2002, 33:1759-1762

7. Saini M, Saqqur M, Kamruzzaman A, Lees KR, Shuaib A, on behalf of the VISTA Investigators: Effect of hyperthermia on prognosis after acute ischemic stroke. Stroke 2009, 40:3051-3059.

8. Boysen $\mathrm{G}$, Christensen $\mathrm{H}$ : Stroke severity determines body temperature in acute stroke. Stroke 2001, 32:413-417.

9. Castillo J, Davalos A, Marrugat J, Noya M: Timing for fever-related brain damage in acute ischemic stroke. Stroke 1998, 29:2455-2460.

10. Greer DM, Funk SE, Reaven NL, Ouzounelli M, Uman GC: Impact of fever on outcome in patients with stroke and neurologic injury: a comprehensive meta-analysis. Stroke 2008, 39:3029-3035.

11. Leira R, Rodriguez-Yanez M, Castellanos M, Blanco M, Nombela F, Sobrino T, Lizasoain I, Davalos A, Castillo J: Hyperthermia is a surrogate marker of inflammation-mediated cause of brain damage in acute ischaemic stroke. J Int Med 2006, 260:343-349.

12. Wang Y, Lim LL, Levi C, Heller RF, Fisher J: Influence of admission body temperature on stroke mortality. Stroke 2000, 31:404-409.

13. Audebert HJ, Rott MM, Eck T, Haberl RL: Systemic inflammatory response depends on initial stroke severity but is attenuated by successful thrombolysis. Stroke 2004, 35:2128-2133.

14. Ernon L, Schrooten M, Thijs V: Body temperature and outcome after stroke thrombolysis. Acta Neurol Scand 2006, 114:23-28.

15. Wong AA, Davis JP, Schluter PJ, Henderson RD, O'Sullivan JD, Read SJ: The time course and determinants of temperature within the first $48 \mathrm{~h}$ after ischaemic stroke. Cerebrovasc Dis 2007, 24:104-110.

16. Idicula TT, Waje-Andreassen U, Brogger J, Naess H, Lundstadsveen MT, Thomassen $L$ : The effect of physiologic derangement in patients with stroke treated with thrombolysis. J Stroke Cerebrovasc Dis 2008, 17:141-146.

17. Millan M, Grau L, Castellanos M, Rodriguez-Yanez M, Arenillas JF, Nombela F, Perez De La Ossa N, Lopez-Manzanares L, Serena J, Castillo J, Davalos A: Body temperature and response to thrombolytic therapy in acute ischaemic stroke. Eur J Neurol 2008, 15:1384-1389.

18. den Hertog HM, van der Worp HB, van Gemert HM, Algra A, Kappelle $L$, van Gijn J, Koudstaal PJ, Dippel DW: An early rise in body temperature is related to unfavorable outcome after stroke: data from the PAIS study. J Neurol 2011, 258:302-307.

19. Den Hertog HM, Van der Worp HB, Van Gemert HM, Algra A, Kappelle $\sqcup$ Van Gijn J, Koudstaal PJ, Dippel DW, PAIS Investigators: The Paracetamol (Acetaminophen) In Stroke (PAIS) trial: a multicentre, randomised, placebo-controlled, phase III trial. Lancet Neurol 2009, 8:434-440.

20. Naess H, Idicula T, Lagallo N, Brogger J, Waje-Andreassen U, Thomassen L: Inverse relationship of baseline body temperature and outcome between ischemic stroke patients treated and not treated with thrombolysis: the Bergen stroke study. Acta Neurol Scand 2010, 122:414-417.

21. Phipps MS, Desai RA, Wira C, Bravata DM: Epidemiology and outcomes of fever burden among patients with acute ischemic stroke. Stroke 2011, 42:3357-3362

22. Leira R, Sobrino T, Blanco M, Campos F, Rodríguez-Yáñez M, Castellanos M, Moldes O, Millán M, Dávalos A, Castillo J: A higher body temperature is associated with haemorrhagic transformation in patients with acute stroke untreated with recombinant tissue-type plasminogen activator (rtPA). Clin Sci (Lond) 2012, 122:113-119.

23. Bamford J, Sandercock P, Dennis M, Burn J, Warlow C: Classification and natural history of clinically identifiable subtypes of cerebral infarction. Lancet 1991, 337:1521-1526.

24. Rampen AJ, van Breda EJ, Dippel DW: Tympanic measurement of body temperature in stroke patients "turned on its ear". J Neurol Neurosurg Psychiatry 2005, 76:1041-1042.

25. Togawa T: Body temperature measurement. Clin Phys Physiol Meas 1985, 6:83-108.

26. Lu SH, Leasure AR, Dai YT: A systematic review of body temperature variations in older people. J Clin Nurs 2009, 19:14-16.

27. Matthews JN, Altman DG, Campbell MJ, Royston P: Analysis of serial measurements in medical research. BMJ 1990, 300:230-235.

28. Kiyatkin EA, Sharma HS: Permeability of the blood-brain barrier depends on brain temperature. Neuroscience 2009, 161:926-939.

29. Wardlaw JM, Dennis MS, Lindley RI, Warlow CP, Sandercock PAG, Sellar R: Does early reperfusion of a cerebral infarct influence cerebral infarct 
swelling in the acute stage or the final clinical outcome? Cerebrovasc Dis 1993, 3:86-93.

30. Levy MM, Fink MP, Marshall JC, Abraham E, Angus D, Cook D, Cohen J, Opal SM, Vincent JL, Ramsay G, SCCM/ESICM/ACCP/ATS/SIS: 2001 SCCM/ESICM/ ACCP/ATS/SIS International Sepsis Definitions Conference. Crit Care Med 2003, 31:1250-1256.

doi:10.1186/1471-2377-12-123

Cite this article as: Karaszewski et al:: Temporal profile of body

temperature in acute ischemic stroke: relation to stroke severity and outcome. BMC Neurology 2012 12:123.

\section{Submit your next manuscript to BioMed Central} and take full advantage of:

- Convenient online submission

- Thorough peer review

- No space constraints or color figure charges

- Immediate publication on acceptance

- Inclusion in PubMed, CAS, Scopus and Google Scholar

- Research which is freely available for redistribution 